\title{
Third-world Oriented Policies of Ahmadi Nejad Government in South Caucasus
}

\author{
Mohammadtaghi Yousefi ${ }^{1}$ \\ ${ }^{1}$ Faculty of Law and Political Science, Islamic Azad University Karaj Branch, Karaj, Iran \\ Correspondence: Mohammadtaghi Yousefi, Faculty of Law and Political Science, Islamic Azad University Karaj \\ Branch, Karaj, Iran.
}

Received: April 27, 2016 Accepted: May 10, 2016 Online Published: June 29, 2016

doi:10.5539/jpl.v9n5p95 URL: http://dx.doi.org/10.5539/jpl.v9n5p95

\begin{abstract}
The collapse of USSR and the independence of the remaining republics from it lead to special geo-politic and geo-strategic changes across the northern borders of Iran. The presence of the influence of regional and trans-regional players in Caucasus that first try to omit Iran or limit the role and presence of Iran in the region and second, have created new sources of threat for Iran in this region has affected the foreign policy of Iran to a significant extent. Given the fact that Caucasus can be the origin of various crises and events such as the separatism, nationalism, and ethnic tension that given the presence of powers such as America and Israel in this region and because of ethnic nexuses can endanger the national security of Iran and Iran needs to have control over the regional entrance gateways to preserve and provide national security and interaction with future challenges. One of the practical approaches in this respect is the fulfillment of the presence and influence of Iran in security issues located among these countries which can reduce the possibility of leaving negative influences of such crises on the national security of our country.
\end{abstract}

\section{Introduction}

After the collapse of USSR three republics were born in the Caucasus region and among them Iran shares common borders with two republics of Azerbaijan and Armenia. Each of these republics has lots of common interests and relations, historical, political, and cultural commonalities with Iran and this issue leads to contradictions, struggles and at the same time good relations among these countries.

Internal interests of these countries along with the interest of the powers to be present in the region and the changes because of the collapse of the USSR are among the influential factors of the Caucasus region. Generally the following four items have the most influence on the evolutions of the Caucasus region:

1) Creating evolutions in many of the international relations concepts particularly redefinition of the concept of threats and security after the cold war.

2) Political and economic chaos of the inside of Russia and its impact on the international position and foreign policy of this country and the lack of movement and deficiency of the Caucasus policy of the Russia is one of them.

3) The western-oriented policy and the influence of the western patterns in southern Caucasus republics such as Azerbaijan and Georgia

4) The rise of the role of energy equations and transport in Caucasus

These evolutions and the influential factors on one side leads to the divergence of the two republics of Azerbaijan and Georgia from Russia and the common wealth countries (SIC) and on the other hand it has facilitated the presence of other powers such as The United States of America and NATO in the region.

Iran by being located in this region and having a common cultural, historic and lingual background with most of these countries has looked at this region the same as other countries of the region. After the collapse of the USSR which had a lot of common sea and land borders with Iran by the creation of independent countries in this area the neighborhood has changed from one to several neighboring countries and the relationship between Iran and these countries which used to be under the relationship with the USSR after the creation of these countries it started with the newly created countries. Some of the relationships between Iran and these countries found newer 
and more expansive aspects.

\section{Statement of the Problem}

Special geography of Iran, intentionally or unintentionally increases the interest of the politicians to regionalism. On the other hand the middle East and Caucasus as newly appeared region that its countries have recently become independent is a new and original environment to create relations and exchange resources and the national benefits. The other point is that the three countries of the south Caucasus because of being neighbor and also having common historical and cultural nexus with Iran have more substrates to increase relations with Iran but the complex and fast evolutions of the recent years can general influence the position of Iran on the middle East as general and the south Caucasus in particular. The apposite management of these conditions in line with the national benefits depends on the precise study and familiarity with the evolutions of the region and the policy of different players and the pathological analysis of the Iranian policy maker.

\section{The Purpose of the Research}

The present study is an attempt to analyze and explore third world oriented strategies in the foreign policy of the Ahmadinejad government in the south Caucasus.

\section{Methodology}

The methodology of the study is descriptive, analytic and historic and the data collection is library form and note making and the use of internet and journals.

Neo-realism, the ruling discourse of the foreign policy of Iran and the vantage point of Dr Ahmadi nejad

Neo-realism is a collective reaction against idealism. Realists intend to make reconciliation between national benefits and trans-national ideals but the national ideals have priority over the trans-national ideals or should have.

Neo-realism school in early 1970s and all along the 1980s was established and under the influence of the behaviorism revolution and by the purpose of making realism scientific came into existence. Richar ashly believes that this theory was formed under the substrate of American issue and problems and economic crises and in fact one of the features of neo-realism is the attention to economic issues.

From the beginning of the revolution and the formation of Islamic Republic of Iran in 1978 two liberal nationalist and Islamic discourses have been dominant in the foreign policy of Iran. Liberal nationalist discourse which emphasizes on secular national state and material national benefits free from Islamic benefits had dominance during the temporary government and the leadership of Banisadr on the foreign policy of Iran. After the resignation of the temporary government and the dismissal of Banisadr in 1981 the general Islamism became dominant over the foreign policy of Iran. Islamic oriented discourse over the last three decades has experienced changes and the result of this inter-discourse is the formation and appearance of five sub-discourses that are: public-oriented idealism, center-oriented expediency, development-oriented realism, peace-oriented democracy, and finally justice-oriented fundamentalism.

After the $9^{\text {th }}$ round of the presidential elections and the start of the presidency of Mahmud Ahmadi nejad the justice-oriented fundamentalism became the dominant policy of the foreign policy of Islamic Republic of Iran. The optimal international system of this government is as follows:

-Creating peace and serenity in the world on the basis of justice and spirituality

-The economic development of all countries of the world and the reduction of the differences between poor and wealthy countries

-The elimination of force and tyranny system in the international relations system so that countries are not divided into two categories of dominating and being dominated

-Eliminating the current challenges of the world such as environmental issues, racial discrimination, poverty and terrorism etc

-Change of the international system and the relations with countries so that it is established on the basis of justice

-Following peaceful settlement of inter-regional and territorial disputes

Ahmadi nejad government followed a mixture of realism and idealism code of action.

In this government the justice oriented discourse in internal scene in accord with the regional balance and fair utility of the political, social and economic opportunities in international scene by the purpose of challenging the arrogant power and the discriminatory system of the international system and the multilateral defense of the 
benefits of Islamic Republic of Iran was planned and practiced. In terms of the foreign policy of Iran and different views inside the country there are two main perspectives:

*Accordance and alignment approach

*Coalition and alliance policy

Both approaches of $<$ Accordance and alignment approach $>$ and $<$ Coalition and alliance policy $>$ with a defensive and practical way but through different methods try to provide the national security of the country over the last years the main difference of the regional presence and the way of establishing balance of utility of geo-politic and ideological elements have been for the foreign policy orientation and depended on the degree of reduction or increase of the foreign policy. At the present time the foreign policy of Iran simultaneously makes use of both methods.

The path and the direction of policy making in the government of Dr. Ahmadi Nejad which is obtained from the results of events and happenings of the three past decades in the international scene. Leaving the tension and trying to obtain the superior power from spiritual, economic and political technological and military which has a special attention to the third world countries and the region under the study in the present research that is southern Caucasus. The main message of the policy making with the neighbors can be summarized in one sentence as follows:

Our security and their security that is neighbors is the same. The attempts made by Ahmadi nejad include the management of the crises and more peace and brotherhood and alliance with surrounding countries.

Relations between Iran and Azerbaijan and the influential factors

Relations with Azerbaijan among the three south Caucasus countries have special sensitivity for Iran. Azerbaijan after Iran and Iraq is the third country with Shia Muslim majority in the world. Along with cultural and historic commonalities the existence of common energy resources in Caspian Sea, profitable markets of Azerbaijan, the need of assistance of Iran for the Nakhjavan region the role of Iran in settling the Gharabagh dispute and finally the presence of America and Israel in this country has complicated the relations of Iran with this country. Despite some positive evolutions in the relations between these two countries taking unfriendly measure by the Azerbaijan government and lack of interest of Baku for the active role of Iran in the region under the pressure of America the development of relations between Baku Tel aviv and the accusations of Baku officials in terms of support of Armenia and the Muslim movements of this country have influenced the development of relations with Baku.

What forms the totality of the Azerbaijan policies specially the foreign policy is not the geo-politic location in proportion to Iran but its weakness and the tendency to make developments the same as nations such as Kuwait, Singapore and Hong Kong rather than an ideological country like Iran and prefers development in the style of west or the friend states and confederating states has made Azerbaijan far from Iran.

Generally the relations between Azerbaijan and Iran can be considered as dependent on factors as follows:

-The difference of view in terms of the legal regime of Caspian sea and the issues about the utilizing the energy resources of this sea

-No role for Iran in Gharabagh peace negotiations and assigning Minsk group for this negotiation

-Strategic treaty of Iran with Armenia under the framework of tripartite treaty of Iran-Armenia-Greece

-Increasing relations between Azerbaijan with America and Israel.

- Losing the obtained opportunities by Iran such as the delay of Iran in recognizing the independence of Azerbaijan Republic and the lack of approval of Iran in the membership of Azerbaijan in the organization of economic co-operations ECO

-Iran has always opposed the allotment of Azerbaijan to this country and this has lead to negative reaction by them

Common religion and creed and deep cultural relations between two countries

-Obtaining a common literature in diplomatic relations

-Continuing the attempts in directing new lines of energy transport from their lands

-Political relations with Caucasus to prevent regional threat elimination against Iran's national security and the economic and cultural benefits.

-Fulfilling the wealth of Iran in the Caspian Sea and the oil resources of the region 
-Benefiting from the communicational position of Caucasus as the substitute path of relation with Europe

-Precise attention and scrutiny of the development of the influence of the United States of America and NATO and the reduction of its classes.

*The influence of the energy resources of Azerbaijan on the security of Islamic Republic of Iran: the presence of oil and gas resources in Azerbaijan is not a threat by itself for the security of Islamic Republic of Iran but the fact that the oil is transferred by which countries and through what path has different influences on the national security of Iran

*The influence of geographic position of Iran on the security of Islamic Republic of Iran: Azerbaijan is located in the joining point of the East-West and North-South

*The influence of population (religion and ethnics) Republic of Azerbaijan on the security of Islamic Republic of Iran: Azerbaijan because of the historic commonalities, traditions and customs and culture is very close to Iran. Although Azerbaijan is the second Shia country in the world but because of the impact of the communist period the sensitivity of the country prevents any type of benefiting religious commonalities in order to fulfill the common religious commonalities.

*The influence of the Azerbaijan on the security of Islamic Republic of Iran: Azerbaijan Republic at different times has tried to pollute the political atmosphere of Iran via pan-turkism. And also the policy of close relations with trans-regional powers such as the United States of America and Israel to flee from the threat of the Russia and attracting support in terms of Armenia in the Gharabagh dispute has been employed. It has become part of the foreign policy of the Azerbaijan Republic

Improving trust and relations with Azerbaijan as a neighbor and as a country whose people have the most commonalities with Iran is one of the principle requirements of national interests and on the top of them is the guaranty of the national security of Iran. The murky relations between the two countries create more capacities for the creation of economic, political and cultural crises between two countries. However the substrates of the development of relations between two sides which can lead to the unity and mixture of the economies of two sides and reduce the tensions to the least need to be attended more seriously.

\section{The Relations between Iran and Georgia and the Influential Factors}

Georgia is located farther from Iran and does not have a common border with Iran. Georgia by having the following principle advantages can be considered as one of the most important countries of the Caucasus. The following five factors are significant that Iran select Georgia as the center of activities in Caucasus.

First: Consolidation of political and social condition and one of the most significant the resolution of Anjazi crisis, conducting the referendum of constitution, administering parliamentary elections and presidential elections

Second: Start of the economic rise by 20\% growth in GDP after 6 years of negative growth experience

Third: Success at the equality of the currency against valid foreign currencies

Fourth: Obtaining the unique opportunity to be selected as the monetary center in the former USSR region

Fifth: Having access to the road and rail transport facilities in Caucasus

*The substitute path of communication of Iran with Europe: Iran-Georgia to Europe can be an apposite substitute of the current path via Turkey. A path which accompanies the inapposite Turkish policies and the positive primary response of the American politicians and Israel faces problems every so often.

*Trade partner: Georgia is critically in need of fossil fuel and many of the Iranian products and can provide a part of the import needs of Iran

*NATO gateway to Caucasus

*Bilateral relations between Iran and Georgia: Bilateral relations between Iran and Georgia have a long history. After the independence of Georgia Islamic Republic of Iran was among the first to officially recognize its independence and started its political relations with it which lead to positive view of the Georgian officials and deepening the relations. The relations between Iran and Georgia from the beginning of the Georgia in 1993 -1996 has an ascending process and from 1997 had descending process in these years Georgia became part of the NATO but after some time the relations between Georgia and Syria because of the accusations of Georgia in the regional crises of Anjazia and souther Oshia and two incidents of terror of president has decreased. All in all the instability of political and social condition in Georgia and as a result the lack of required security for the investment and risk taking relative insecurity in Azerbaijan-Armenia line for the access to the Georgia, bad 
quality of the roads and cut of railroad and lack of the possibility of high investment are among the reasons of the fall of investment in Georgia. Similarly in the field of cultural relations seven co-operation treaties were signed.

\section{The Relations between Iran and Armenia and the Influential Factors}

Armenia as an enclosed country in land from geo-political aspect has several limitations. This country to some extent in alliance with Russia and the natural assistance of Iran and the help of Armenian in west and the western countries have been able to keep itself and does not come short in front of its rival. But this condition will face Armenia with more critical problems. Iran with absolute caution developed its political relations with Armenia after the independence of this country.

To escape the economic crisis after the independence this country has followed the economy on the basis of free market system by an emphasis on liberating economy, general economic stability, and change of economic structure. Armenia's economy is slowly and gradually developing. Some limited investments have started which can influence the revival of the economy. The extreme economic weakness of Armenia would also affect the land exchange and the flexibility of the Armenians.

The impact of the changes of neighboring countries on each other: The continuation of the Gaharabag crisis and the staying of Russian forces in Armenia and the opposite interests of the regional players and trans-regional have increased the sensitivity of the issue. Over years after the independence of Armenia in addition to the 42 kilometer common border of Iran and Armenia and the $100 \mathrm{~km}$ common border of Iran and Azerbaijain is under the control of the Armenians and in active struggles of two neighbors the spread of struggles and the overflow of the war refugees in the borders of Iran has been experienced and there is a possibility of its reoccurrence. Also the different views of Armenian government about the Garabagh dispute and other strategic evolutions have a significant impact on Iran.

*Geo-political importance of Armenia for Iran: Armenia with the present territory between turkey and Nakhjavan in west and Azerbaijani in east is enclosed. This position on one hand causes turkey as one of the most important rivals of Iran in the region in following the policy of Pan-turkism and the expansion of its influence in Azerbaijan and the central Asia countries not be able to communicated with direct land relations and easily benefit from its expansive facilities and Armenia is a block against this expansive relation and on the other hand for the relationship with Nakhjavan has to make use of the land of Iran and this need in fulfilling the needs of Nakhjavan can moderate the anti-Iranian views of Azaris.

*Armenia a substitute path for the relationship with Europe: Over the past years the Iraq path because of the war between Iraq and Iran and the Caucasus path because of the approaches of the former USSR was closed against Iran and turkey was the only way of Iran Europe path. By the independence of Georgia and Armenia countries and the establishment of relative security in the path and the borders to reach the Black Sea this path can be an apposite path for the aforesaid path

*Bilateral relation between Iran and Armenia: The start of bilateral relations between Iran and Armenia coincide the rise of conflicts with Azerbaijan in the Garabagh region. The nationalist Azari Irani and the ideological mentalities about the Azerbaijan people lead to the creation of conditions that as a result of it fluctuating behaviors of Iran concerning the Caucasus issue in proportion to the Caucasus republics. The relation between Iran and Caucasus not in the form of a significant neighbor but as a function in proportion of the behavior of Azerbaijan was arranged. But at the present time new factors have entered into the relations between the two countries and have improved the quality and quantity of it. The change of the vantage point of the official authorities of Iran concerning the Armenia and active and serious planning in the region by considering the plans and the purpose of the players in that country. The rise of the economic and security needs of Armenia to economic needs in the region calls for the revision of the foreign relations and attention to Iran-Armenia-Europe line by economic projects and the Iran-Armenia-Russia path in security issues.

\section{Discussion and Analysis}

For the Islamic Republic of Iran the Caucasus region is as one of the inter-regional areas. The announcement of Caspian Sea as a region of strategic interest of America, gradual expansion of NATO to the region and the attempts made in the region by the NATO officials and also the demand of some of the regional states to open military headquarters in their lands are among the most important issues which have concerned Iran in the northern borders and naturally the balance of nexus with Russia against America and Turkey. However, some factors and issues prevented the expensive role and influence of Iran in southern Caucasus. Cold relations of Iran with west and in particular the struggles between Iran and the United States of America and also the fact that Iran 
considers the expansion of NATO into the east lead to the expansion of the relations with Moscow.

Iranian statesmen had to follow the practical foreign policy in the region by the purpose of establishing balances and apposite relations with the neighboring countries accordingly the main principle of establishing interaction between two elements of geo-politic and ideological is in line with the arrangement of the foreign policies. Similarly Iran can consider the relation with turkey to direct the foreign policy in a form of $<$ non zero sum $>$ in which the best policy to secure the national security and interest is $<$ win-win $>$ approach.

Iran has to accept the presence of the United States of America next its borders as a fact and by following the $<$ active defense $>$ policy and by <efficient presence $>$ in political, security issues of the region of the issues around it, political-strategic interest follow at the same time and consolidate its influence in this sensitive region. By a look at the performance and the goals of the Islamic Republic of Iran in the southern Caucasus in recent years in the governments of Ahmadi Nejad it shows that Iran observes the foreign policy of realistic politics. Although the confronting policies of America against Iran has complicated the issue of the presence of Iran in regional issues what can be inferred fro the evidences Iran has accepted the security challenges or at least some of the influences on the region and to some extent tries to eliminate them in terms of the security-political issues there is a need of a comprehensive security system which is a regional approach because Caucasus as a single security unit requires a regional approach and the individual approaches of every single country of the region will not be fulfilled unless without considering the security concerns and needs of other countries despite the recognition of this necessity by most of the countries of the region because of their various vantage point in foreign policy and security it seems that a bi-pole system is appearing that the first pole consists of Iran, Armenia, Russia and the other pole is Georgia, Azerbaijan, Turkey and the United States of America

\section{Conclusion and Suggestions}

In this study first the theoretical discussions of foreign policy of Iran in terms southern Caucasus was analyzed in terms of neo-realism and then the factors limiting the movement of Iran in the aforesaid region which are as follows:

1) The strategy of the United States of America on the basis of the game everything without Iran

2) Regional competitions by the zero sum of the main regional players, superior powers and the regional rivals

3) Lack of the power of Iran in strategic capacity and orientation in terms of security-political issues of the region such as Gharabagh and southern Oushai

Improving trust and relations with Azerbaijan as a neighbor and as a country whose people have the most commonalities with Iran is one of the principle requirements of national interests and on the top of them is the guaranty of the national security of Iran. The experience of the recent decade showed that presenting any plan without considering the legal interests and goals of the beneficiary countries has no end but failure and imposing heavy expenses on the people in the region. In the current complex scene the end of the job requires moderate rationale and understanding identity evolution and the rational of power in the world and the consistent security in the region without considering the legal interests of the regional states will not be obtained. Russia, Iran, Turkey as the inseparable neighbors of the Caucasus should not feel a serious danger from this region. Therefore, on the basis of the aforementioned issues and by considering the fleeting and changing condition of affairs in the region of Caucasus and becoming a barrier geo-political region between Iran, Russia and Iran the following approached to keep the geo-political position and the national security of Iran in the Caucasus seems apposite:

-It is necessary for Iran to make use of its relative advantages such as the communicational road line to the south, security of the lines and the political stability consolidate economic relation regardless of the religious and cultural relations. Establishing economic relation would have different aspect where the religious and cultural relations will be possible.

-Since the majority of the energy experts believe that Iran is the most economic and secure place of transferring energy to the markets of the world and to confront the policy of America to prevent the transference of energy from Iran it seems that the continuation of the oil exchange (swap) and meeting the interests of the Caspian Sea neighboring countries would provide the interests of Iran.

Given the tension and dispute between Iran and the European countries in the government of the Ahmadi nejad over nuclear issues it seemed that the focus of the foreign policy of Iran is over the surrounding countries and particularly the southern Caucasus has been focused. One-sided visa cancelation which was imposed from 2009, allotting transit facilities for the transport of goods in the land border entrance and the exit of Jolfa to the Nakhjavan republic providing the electricity of Nakhjavan republic, all show the provision of optimal opportunities to warm up the relations but by the lack of political cognizance of the opposite side one after the 
other is omitted. Creating media war by the officials of Baku against Islamic Republic of Iran, inviting the prime minister of Zionist regime, creating limitations for the Iranian citizens and businessmen in that country all reflect the untrustworthy policy of Baku against the good will displayed by Iran that the tenth government should take apposite measures to eliminate it.

\section{References}

Abdolhoseyni, H. (1999). The role of American policies in the relations between Iran and Azerbaijan M.A. thesis. p.100-103.

Dosoti, J., \& Faltzgraf, R. (n.d.). contradictory view in international relations. translated by Alireza Tayyeb and Vahid Bozorgi, Gos publications Tehran. p.145.

Ebrahime Sadig, S. (2004). relations between Iran and Caucasus and central Asia Dadgostari publications, Tehran, 130-131.

Herzig, A. (1996). foreign policy of Azerbaijan and Armenia seasonal studies of Caucasus and central Asia Tehran, p.27.

Herzig, E. (1996). Iran and formet USSR studies translated by Kamelia agshami Akbari international political studies Tehran, p.24-29.

Jahangire karamisouther oustya. (2009). $16^{\text {th }}$ conference of Caucasus and central Asia Tehran international political studies 2009, p48-51.

Jrard, L. (2004, summer). foreign policy of Armenia seasonal on Caucasus and central Asia $13^{\text {th }}$ year fourth edition n.46, p.98.

Karami, J. (2009). Iran and south oustiya $16^{\text {th }}$ conference on studies on Caucasus and central Asia Tehran. p.58-61.

Mahizade, G. (2009). security and economic policies of Caucasus and central Asia bishe publications Tehran 2009 , p.78.

Mahmod vaezi. (2009, summer). Interests of Russia and West in Caucasus and central Asia and multilateral roles studies of Caucasus and central Asian. 66.

Mahmod vaezi. (n.d.). causes of instability in Caucasus and central Asia and the political approaches. pp.8-9.

Mohammadreza. (1994, Fall). Caucasus and central Asia entrance into new geo-political space formation. seasonal studies of Caucasus and central Asia, (6), 115.

Moradi, M. (2006). Iran European Union relations horizons in terms of Caucasus and central Asia Tehran, p.44-46.

Norozi, N. M. (n.d.). Iran and turkey confrontation in Caucasus and central Asia $9^{\text {th }}$ year 2000, 120-122.

Rasol, S. E. (2010). the impact of the dominance of Iraq 2003 on the security order of the Persian Gulf Azad University of Karaj 2010. pp70-77.

Seyyedi, M. (2009). geo-political factors influencing Azerbaijan and the national security of Azerbaijan n.65, p.86-88.

\section{Copyrights}

Copyright for this article is retained by the author(s), with first publication rights granted to the journal.

This is an open-access article distributed under the terms and conditions of the Creative Commons Attribution license (http://creativecommons.org/licenses/by/3.0/). 